\title{
The Development of Gamification Model Assisted by Online Learning to Improve the Quality of Student Learning in Economic Education at Pamulang University
}

\author{
Rusmaini $^{1}$, Lodya Sesriyani², Saiful Anwar ${ }^{3}$ \\ Pamulang University \\ dosen02066@unpam.ac.id ${ }^{1}$,dosen01852@unpam.ac.id ${ }^{2}$,dosen00902@unpam.ac.id ${ }^{3}$
}

\begin{abstract}
Gamification is an integrated process in a game in the form of a website, social media, and daily operational activities, moreover it can motivate students to be active in learning process. The aim of this study is to improve the quality of student learning by producing a chapter on the module for renewal of economic education learning. The research method used is Research and Development (R\&D). In this research, The application of gamification learning model assisted by online learning consists of 3 (three) stages consisting of limited trials, extensive trials and field trials. The results showed that: (1) Development of gamification learning models assisted by online learning was declared valid for use; (2) There is a significant difference in the quality of student learning before and after using online learning assisted gamification learning models. Therefore, this learning model is very effective to be applied in lectures.
\end{abstract}

Keywords: Gamification, Social Media, Online Learning

\section{Introduction}

Indonesia is currently striving to reform learning to be better, to achieve better learning, educators in an educational institution need to learn various approaches, methods, strategies and techniques and tactics. Not only that various learning models can also be developed by educators in conducting academic research or classroom action research. Coupled with the technological sophistication of educators is expected to be able to provide quality learning that is creative and innovative. But the problem that often occurs in an institution is that educators have not been able to develop learning models using technology. So that learning becomes inflexible with the times and has an impact on the quality of student learning that is less effective.

Based on the learning conditions described above, the researcher tries to overcome these problems by developing a learning model that is used by educators precisely in the economic education program of the teaching faculty and education sciences. Educators in the economic education study program of the teacher and education faculty are required to be able to master teaching materials and ways to teach. Thus, it is expected that this way of teaching educators can provide good quality of learning to students and can be applied by students in the learning process or in the field experience. One of the learning models that can be developed and applied by educators by utilizing technological sophistication is the learning model of gamification. This gamification learning model is a technique that is designed in the form of a game. This learning model can be applied by utilizing game-based mechanics, art, and 
students 'way of thinking based on games and students' ways of promoting the subject matter being studied. Not only that this gamification learning model works through a sophisticated technology and makes the technology from the one used more interesting. So with this interest, students as game users will be able to be actively involved in the learning process.

This gamification can also help students to solve problems, making students who have a tendency to play games can use game applications as learning media. Gamification is an integration of game elements and game thinking in activities that are not games (Kiryakova, 2014). Gamification is also interpreted by Zichermann \& Cunningham (Romdhoni \& Wibowo, 2014) as the process of using game design techniques and game mechanisms in nongame contexts to bind users to achieve a goal. While Jusuf, Heni (2016) describes gamification as a learning approach using elements in games or video games with the aim of motivating students in the learning process and maximizing feelings of enjoyment and engagement with the learning process.

This gamification learning model has been widely studied by previous researchers, one of which is Saiful Anwar (2018) in his research stating that: 1) the learning process in the subject of Renewal of Economic Education Learning can be done with the concept of gamification by combining face-to-face learning in the classroom with online learning learning ; 2) students' responses in the learning process with the concept of gamification were mostly interested because it was new to them; 3) there is a nurturant effect as long as the concept of gamification is applied in class. In developing the gamification learning model the researcher utilizes virtual learning or what is commonly referred to as online learning. Learning methods carried out in a modern way will make students more active than traditional learning methods. E-learning is one of the methods used in virtual classroom learning. E-learning is not only as a substitute for learning methods but can also be used as a substitute for learning material that is usually done face to face. With the help of e-learning, students become more skilled in using IT technology and can maximize the ability of these students. The purpose of this study is to improve the quality of student learning by producing a chapter in the module for renewal of economic education learning. So that the chapter can be used by students for reference learning, especially in the renewal courses in economic education learning.

\section{Method}

This research was conducted on students who are pursuing courses in the renewal of economic education learning precisely in semester V. In accordance with the issues studied, this research was conducted using the Research and Development (R\&D) research method. Research procedures undertaken by researchers in this development are adapted from the development steps developed by Borg \& Gall (2013) which state that it is possible to limit research on a small scale, including limiting research steps. The implementation steps are adjusted to the needs of researchers. Given the time constraints that researchers have, the steps are simplified into three steps of development. The development steps undertaken by researchers are: limited trials, extensive trials and field trials.

Data analysis techniques used in this study consisted of 4 types, namely 1) Validation data analysis, 2) Practical data analysis, and 3) Data analysis of concept understanding (Arikunto, 2009). The Learning Module that was developed was tested by comparing it with conditions before and after using teaching material (before-after) in the experimental class and the control class (Sugiyono, 2012). 


$$
\begin{array}{|llll|}
\hline R & \mathrm{O}_{1} & \times & \mathrm{O}_{2} \\
\mathbf{R} & \mathrm{O}_{3} & \mathrm{O}_{4} \\
\hline
\end{array}
$$

Annotation

$\mathrm{R}=$ Experimental and control group

O1\& O3 = Both groups were observed with a pre-test to determine their initial abilities

O2 = Classes that apply learning with gamification learning models

O4 = Classes that do not apply learning with gamification learning models

In classes that apply learning with gamification learning models. Then the teacher needs to pay attention to the steps of implementing gamification in learning. The steps according to Heni Jusuf (2016) are as follows:

a) The teacher first divides the subject matter into sub-materials from general to specific. In each sub material there are quizzes and practice questions. Students who successfully carry out the quiz properly will get a reward or award in the form of points or additional value.

b) The teacher separates materials into each different level or level. So that each student will get new knowledge in accordance with the level / level to be pursued; students cannot take the next level / level if the previous level is not done well.

c) The teacher records each point / score that students can get based on the level they have taken. So that students become the focus to be able to create more points in the game;

d) There is feedback in the form of rewards to students who can win the game well. These rewards can be in the form of additional points or values, certificates and other awards and then posted through social media or the internal website of the school / institution.

e) There is a time duration for completing challenges at each level or level so students must complete the challenges according to the designated time. Students who cannot complete the challenge from the allotted time are not allowed to take the game at the next level / level.

f) Each group must collaborate with each other together to complete the challenges given;

g) Students are introduced to concepts and are able to interpret learning topics, where each student is able to produce the best work;

h) Students are given the freedom to give assessments and comment on the results of work from different groups. It aims to make students able to appreciate criticism and comments from other groups;

i) There are extra bonuses or prizes when students are able to work on new challenges that are more difficult;

j) The existence of a second plan in the form of backup scenarios, so that if students are unable to overcome challenges then students can find a solution;

k) The teacher must be able to recognize what are the driving factors and inhibiting factors of students in the learning process;

1) There are learning facilities that can create student characters to play during the learning process

m) There must be a special leaderboard that can motivate students to compete and collaborate in play during learning.

From the steps of the gamification learning model above, it can be concluded that gamification learning is learning with a tiered game technique with different levels of difficulty at each level, each group or student who successfully runs a challenge at each level 
will get an award from the teacher either in the form of adding points, adding value and other rewards, the teacher is tasked with recording scores on each student's answer on the standings board. So that students will be more excited to collect points.

\section{Result and Discussion}

The existence of learning models especially how to teach educators is very important to support the learning process. The learning model used must also be in accordance with the needs of students and in accordance with the learning outcomes of the course. In developing the learning model, students of the Economic Education Study Program Faculty of Teacher Training and Education in Pamulang University need a learning model that can utilize technology and assisted with e-learning so that learning can be done anytime and anywhere in accordance with the stipulated time, students become more skilled in using IT technology, and students are able to develop the abilities they have.

\subsection{The Validation Test Results of Elearning Assisted Gamification Learning Model for Economic Education Study Program Students, FKIP, Pamulang University}

In conducting the validation test, researchers involve several experts in accordance with their fields. Based on the results of the expert validation test the following assessment results are obtained.

Table 1. Validator Assessment Results

\begin{tabular}{ccrccc}
\hline & & \multicolumn{3}{c}{ Assessment } & Averange \\
\hline No & Aspect & Expert 1 & Expert 2 & Expert 3 & \\
\hline 1. & Content & 21 & 20 & 23 & \\
2. & Linguistics & 22 & 23 & 22 & \\
3. & Presentation & 20 & 22 & 23 & \\
4 & Grafting & 21 & 20 & 21 & \\
& Total & 84 & 85 & 89 & 86 \\
\hline
\end{tabular}

From the data in the table it is known that the average score of 86 ratings is very good. In the validation process, there are three expert validations consisting of expert content validation, language expert validation and instructional media validation. The results of the validation are the material experts suggest to improve the content of learning materials to be sharper and more applicable, linguists suggest using communicative language and the media experts suggest that the appearance of the media used is more interesting and varied.

\subsection{Test Results of Elearning Assistance Gamification Learning Model for Economics Education Study Program Students, FKIP, Pamulang University Subjects Renewal of Economic Education Learning}

The results of the effectiveness of the learning model are determined by obtaining initial and final grades. To determine the difference in acquisition of these values, the difference test is carried out. The difference test here is intended to compare the average of a variable 
between the initial and final outcome values. The statistical hypothesis is used as follows. H0 : $\mu_{1}=\mu_{2}$ (average initial value is the same as the final grade), $\mathrm{H} 1: \mu_{1} \neq \mu_{2}$ (average initial value is not the same as average final grade). Based on the data in the table it can be seen that from the similarity value of the two variances obtained $\mathrm{F}=1,857$ which assumes that the two variants differ from the value of $\mathrm{t}=11.257$ with degrees of freedom $(\mathrm{df})=141$, and $\mathrm{sig}=$ $0.176=17.6 \%$ (more from $5 \%$ ). This means that $\mathrm{H} 0$ is accepted, meaning that both samples have the same variance. Next selected Equal Variance Assumed, obtained sig $=0,000=$ $0 \%<5 \%$. This means that $\mathrm{H} 0$ is rejected, meaning that the two populations have different mean completeness.

Test the similarity of the two averages between the initial test and the final test using the following hypothesis.

Ho: There is no difference in learning outcomes between students on the initial and final tests.

Ha: There are differences in learning outcomes between students on the initial and final tests.

As for knowing the truth of the hypothesis used $t$ count $>t$ table. Based on the $t$-test price it is known that $\mathrm{t}$ is 11,257 with a significance level (sig) of 0,000 and degrees of freedom (df) $=$ 141 with a confidence level of $95 \%$, it can be concluded that Ho is accepted and there is a significant difference between the average scores of students before and after learning by using the gamification learning model because $t$ arithmetic (11.257) $>\mathrm{t}$ table (0.679). Thus, it can be said that the gamification learning model for students of the Department of Economic Education, FKIP University of Pamulang can improve the quality of student learning, especially in courses on the renewal of learning economic education. Therefore, the teaching material is effective and accepted.

\section{Conclusion}

Based on the description of the results of the study, it can be concluded that the gamification learning model for Economics Education Study Program students, FKIP Pamulang University is as follows: (1) Development of an online learning assisted gamification learning model is declared valid for use; (2) There is a significant difference in the quality of student learning before and after using online learning assisted gamification learning models. Therefore, this learning model is very effective to be applied in lectures.

Based on the above research conclusions, here the researchers submit some suggestions as follows:

a) By looking at the findings above the researchers suggest that lecturers of economic education in the faculty of education and education at the University of Pamulang, especially those who support Education Learning Renewal courses, be able to use learning models that can utilize technology such as gamification learning models assisted by online learning;

b) The implementation of the learning model carried out by the lecturer of the Faculty of Economics and Education at the University of Pamulang is still not maximal, therefore between lecturers and students should be able to work together to improve the implementation of the learning model by utilizing technology to be able to provide better quality of learning. 


\section{References}

[1] Arikunto, Suharsimi.: Research Procedure A Practical Approach. Jakarta:Rineka Cipta. (2009)

[2] Jusuf, Heni.: Penggunaan Gamifikasi dalam Proses Pembelajaran. Jurnal TICOM. Vol. 5 No. 1 September 2016. (2016)

[3] Kiryakova, Gabriela \& Angelova, Nadezhda \& Yordanova, Lina.: Gamification In Education. Bulgaria: Faculty of Economics Trakia University. (2014)

[4] Romdhoni, Fachri, Hilmi \& Wibowo, Radityo Prasetianto.: Penerapan Gamification Pada Aplikasi Interaktif Pembelajaran SQL Berbasis Web. Jurnal TEKNIK POMITS Vol. 1 No 1 tahun 2014. (2014)

[5] Saiful Anwar dkk.: Efektifitas Gamification Berbasis Blended Learning Pada Mata Kuliah Pendidikan Ekonomi. Vol. 6 No. 1 Hal 5-14. p-ISSN 2303-324X, e-ISSN 2579-387X. (2018)

[6] Sugiyono.: Quantitative, Qualitative, and R\&D Research Methods. Bandung: Alfabeta. (2012) 